\title{
Texas forced life-support case could happen in Canada
}

A controversial case in which a Texas hospital kept a braindead, pregnant woman's body on life-support against her family's wishes could be repeated in Canada, say ethicists.

Marlise Munoz's body will soon be buried by her family, after a judge ruled Jan. 24 that John Peter Smith Hospital in Fort Worth, Tex. had misapplied a state law in refusing to withdraw lifesaving treatment. The hospital acceded to the ruling and withdrew life-support on Jan. 26. It had kept Munoz's body in intensive care over family objections for nearly two months in a bid to save her still living-fetus.

The hospital "appreciates the potential impact of the consequences of the order on all parties involved and will be consulting with the Tarrant County District Attorney's office," Jill Labbe, vice president of communications and community affairs, wrote in a statement to CMAJ after the ruling.

The case has attracted international attention and become a lightning rod for debate about patient, family and fetal rights at end-of-life - a legal and ethical grey zone that remains contentious, even in Canada, which according to experts is less politically polarized.

Canadian consent statutes don't speak to "whether or not it is acceptable to keep the body of a deceased person functioning to ensure that a pregnancy can be carried to term," says Udo Schüklenk, Ontario Research Chair in Bioethics at Queen's University in Kingston, Ontario. "The odds are that life support would be switched off, but nothing could stop either party from going to court over such a matter."

Both the Supreme Court of Canada and provincial legislatures have confirmed the fundamental right of individuals to refuse medical intervention, including by advance directive or a substitute decision-maker.

But determining how far such protection might extend after death, particularly when a living fetus is involved, is

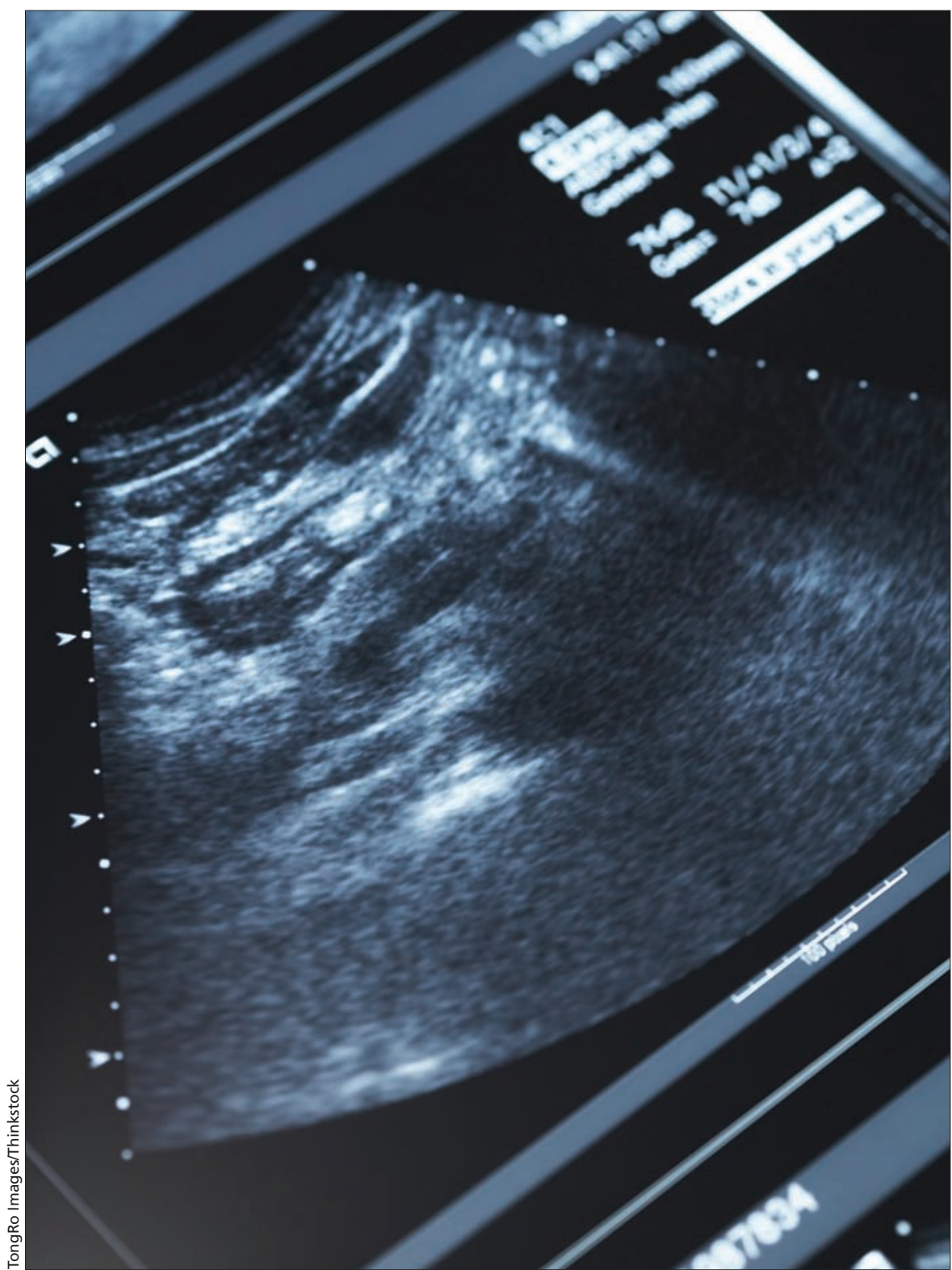

A fetus has no legal standing in Canada, but that doesn't preclude it having ethical interests, say experts.

"very messy, both ethically and legally," says Kerry Bowman, a bioethicist at the University of Toronto in Ontario. "The person is now technically dead, so you no longer need consent of any form ... although what typically happens is you respectfully make plans as to what point you will stop the life-support."

Although a neurologically compromised, pregnant woman is "legally one patient, ethically it's an open question and many people feel we essentially have two," Bowman adds.

According to Dr. Eugene Bereza, director of the Biomedical Ethics Unit at McGill University in Montréal, Quebec, the issue becomes more complicated as a pregnancy progresses. He cites the example of a living, competent woman refusing a cesarean delivery, although 
it's clear her otherwise healthy, full-term baby will die.

"Any reasonable person would be hard-pressed to say the fetus has no ethical interests when there's two centimetres of tissue separating it from legally being recognized as a person with a full life ahead," says Bereza. "It's not that the interests of the fetus have no ethical bearing, but how much and to what extent is clearly an issue."

Factor in a deceased mother and "there's no recipe book" for navigating such a situation, he adds. "Physicians tend not to be keen on continuing futile care, but I certainly know of major tertiary care teaching hospitals where, because of the cultural community involved, physicians would be more resistant to withdrawing life-support."

According to Arthur Schafer, director of the Centre for Professional and Applied Ethics at the University of Manitoba in Winnipeg, using a braindead woman as a kind of "cadaveric incubator" could be interpreted as offering "indignity to a dead human body" - an indictable offence under the Criminal Code.

However, Canadian courts have historically been lenient with physicians who err on the side of life. Bereza cites the landmark Ontario case of Malette $v$. Shulman, in which a physician who knowingly administered a blood transfusion to an unconscious Jehovah's Witness patient was found liable for battery, but ordered to pay only nominal damages.

"If the court really thought this physician committed an egregious crime, it wouldn't have slapped him on the wrist with $\$ 20000$ in damages," he explains. "That's probably less than the court fees."

Margaret Somerville, founding director of McGill University's Centre for Medicine, Ethics and Law, says any legal dispute over continuing life-support for a deceased, pregnant patient would hang on "whether the physician acted with reasonable care."

"I think there's a strong moral intuition that it's a very serious thing to expressly and intentionally let an unborn child die," she adds. Ultimately, however, "it would be a novel interpretation of law you would be looking at."

Indeed, Bowman contends it's more likely the opposite conflict would occur. "Even if the family was begging to continue life-support, most Canadian physicians would not want to if the patient had been deemed legally dead."

In cases involving a living fetus, Bowman has "never seen a situation where we've moved against the wishes of a family."

That such a case could occur in Canada highlights that the ethics around end-of-life decisions are more ambiguous than many realize.

"Most people believe that end-oflife decisions are really solid once they are stated, or that your substitute can make them for you without question," says Bowman. "This shows that there are situations in which that's not the case." - Lauren Vogel, CMAJ

CMAJ 2014. DOI:10.1503/cmaj.109-4711 